\title{
Triumphs and Trials: Probing the Pre-service Teachers' Practice Teaching Experiences
}

\author{
Maria Leodevina C. Batugal \\ College of Education, St. Paul University Philippines, Tuguegarao City, Philippines
}

Received March 16, 2020; Revised May 12, 2020; Accepted May 20, 2020

Copyright $(02020$ by authors, all rights reserved. Authors agree that this article remains permanently open access under the terms of the Creative Commons Attribution License 4.0 International License

\begin{abstract}
This study explores the extent of the performance of the pre-service teachers as they engaged themselves in actual teaching. It further investigates on what are the highlighted experiences as they performed their responsibilities as pre-service teachers. A mixed-method was utilized to gather pertinent data. The quantitative research method, with the use of a survey questionnaire, was adopted to rate the pre-service teachers' teaching performance. The raters were the teachers who directly supervised the pre-service teachers. Frequency and percentage distribution were used to confirm statistical assumptions for the background variables of the participants. The weighted mean was utilized to interpret the obtained responses using a 5-point Likert scale. Moreover, a qualitative research method through documentary analysis was used to examine the personal experiences of the pre-service teachers. Open-ended questions were asked from them. The theoretical framework used in this study is anchored on Kolb's experiential learning theory. Results reveal that the pre-service teachers' performance was rated from very good to excellent. The narrative essays of the pre-service teachers disclose their triumphs and trials. The themes that emerged from their essays include self-efficacy, character building, classroom management, and the production of teaching resources. The data gathered provided validation and a solid foundation for drawing out conclusions of this study. The results will aid future pre-service teachers to face with confidence of the challenges of actual teaching. Moreover, this study will be a basis in formulating initiatives to improve the Teacher Education Program of St. Paul University Philippines. Implications and directions for future research are likewise discussed.
\end{abstract}

Keywords Practice Teaching, Classroom Management, Pre-service Teachers, Teaching Resources, Self-Efficacy

\section{Introduction}

Teaching is more than a noble profession; it is a vocation. Vocation comes from the Latin word "vocare," which means "a calling." Buijs [1] refers to it as any career choice, and more specifically, it connotes a calling in life that consists of distinctive roles or functions. God is the foundation of vocation. Thus every teacher is called to a particular ministry, the ministry of teaching like Jesus, who himself is a teacher, a rabbi during his earthly life, and ministry. As a teacher, Jesus taught in the temple courts, synagogues, by the lakeside, and wherever people were gathered around Him. The gospels contain many references to Jesus' teaching. It is recalled that he taught with profound knowledge, marked by a distinct methodology. He used parables. It was such a unique and exceptional style of his teaching ministry which drew the people to himself and led them to a renewed life.

The significant role of the teacher is rooted in Jesus' ministry of teaching. From the onset, the life of a teacher should be an inspiration from Jesus' life and ministry. The life of a teacher commences in their practice teaching. This is the hallmark of their journey to real teaching, from theory to practice, which is also called the initial teacher training. The initial teacher training is appropriated to provide the pre-service teachers with profitable opportunities to demonstrate the acquired competencies, which include pedagogical knowledge, skills, attitudes, and values in practice. The combination of these competencies capacitates the pre-service teachers in performing their given roles. Jusoh [2] articulates this as a time for student-teachers to experiment with the knowledge obtained and put them into practice. Competency is an essential aspect of the educators' quest for quality and excellence. In a research conducted by Ulla [3], it is mentioned that pre-service teacher training is one of the most critical aspects of every teacher's education curriculum because it prepares student-teachers to become qualified teachers in the future. 
The practicum program of the pre-service teachers is designed to prepare them to meet the challenging occupation and teacher licensing requirements. Thus, earning a degree and completing the teacher preparation program, the prospective teachers should develop the essential skills that would make them effective and efficient teachers in the future. The study conducted by Anderson \& Mayer-Smith [4] resulted that the student-teachers' experienced profound changes in their views of teaching and learning. The participants, as articulated in this same article, further developed and broadened their views of education, increased understandings of the educational theories of constructivism, and of 'teachable moments.' Grootenboer [5] calls this an opportunity to develop teaching skills and knowledge in a classroom setting. Further, he stated that these experiences are very powerful in shaping student-teachers' views of teaching.

The practice teaching holds great importance in the pre-service teachers' teaching efficacy. This was found out in a research conducted by Main \& Hammond [6] that self-efficacy beliefs among the student-teachers were generally high and were even higher after their practicum. This is also confirmed in a study conducted by Martins, Costa, \& Onofre [7] that the role of the practicum in teacher education programs and the importance of training supervisors in the implementation and management of the training experience contributed to the student-teachers' self-efficacy development. This present study supports the previous findings that self-efficacy among the pre-service teachers is developed as they conduct their practice teaching. Another research conducted by Dickson, McMinn \& Kadbey ascertained that teachers with more experience were far more likely to express confidence in their abilities (self-efficacies) [8]. Psychologist Albert Bandura initially proposed the concept of self-efficacy. According to him, the idea is a personal judgment of "how well one can execute courses of action required dealing with prospective situations" [9]. In this present research, self-efficacy is explained as the conviction of the pre-service teachers to guide and direct their students to success.

Moreover, the practicum experience helps in building resilience among pre-service teachers. The diverse group of students with which the pre-service teachers dealt within their practice teaching allowed them to experience challenging behaviors of students. It was through these experiences that allowed them to think more intelligently of certain mechanisms to cope with demanding and difficult classroom situations. Consequently, making them more resilient in every challenging circumstance they come across allows them to develop coping strategies that strengthen their wills to face the real-life challenges of teaching in the future.

The pre-service teachers' journey to practice teaching is arduous yet rewarding. Their activities can be challenging that may be regarded with optimism or just the other way around. Some studies show that pre-service teachers perform satisfactorily and develop strategies to cope with the demands of their classrooms, but some, however, "fail," as cited by Knowles, Skrobola, \& Coolican [10]. Knowles et al. [10] further mentioned that they [pre-service teachers] either given an unsatisfactory grade for obtaining provisional teacher certification or a teaching position. A failing grade may also be given. The previous findings relate to the present study as it explores on the pre-service teachers' teaching performance, the triumphs, and trials they had experienced. The result of a survey conducted by Putman [11] indicated that pre-service teachers demonstrated inconsistent beliefs about the philosophies of classroom management developed as part of university coursework.

Furthermore, this present research, which explored the triumphs and trials experienced by pre-service teachers, finds similarity in a study conducted by Caires, Almeida \& Vieira [12] among 295 students. The result showed the difficulties of student-teachers in their practice-teaching. It revealed the challenges they experienced, such as stress, sense of weariness, 'vulnerability' and others. Moreover, they also perceived positive perceptions regarding their growing knowledge and skillfulness, their sense of efficacy, flexibility, and spontaneity in their performance and interactions. They also achieved reasonable levels of acceptance and recognition within the school community and positive evaluation due to the guidance and support provided by their supervisors. In another study conducted by Brown, Lee \& Collins [13], findings indicated that pre-service teachers' perceptions of preparedness and sense of teaching efficacy both increased significantly from pre-student teaching to post-student teaching. Interestingly, Plotnikova \& Strukov articulated that today's graduates of higher educational institutions are required to have new professional thinking, high mobility, competence, tolerance, and focus on intra-group activities carried out in teams [14].

The pre-service teachers of whom the present researcher mentored were provided with opportunities to conduct their practice teaching both in the private-sectarian and public non-sectarian schools. These environments and the wide arrays of classroom experiences given to them were greater chances of having extensive exposure to diverse students that allowed them to test their critical thinking, creativity, commitment, character, resilience, and facilitating skills. Thus, this study sought to investigate what is the extent of the performance of the pre-service teachers as they engaged themselves in teaching in their laboratory school. It further explored what are their highlighted experiences as they performed their roles as pre-service teachers, the triumphs and trials they experienced in the various preparations of their actual teaching demonstrations. Likewise, it investigated the experiences they encountered with their students and 
experiences having been observed and assessed by their supervising teachers. Hence, the results of this present research will help mentors and teacher-supervisors to facilitate future pre-service teachers in guiding them to face with confidence of the challenges and their roles as pre-service teachers. Likewise, it provides a database of pre-service teachers' performance and experiences, which will be a basis in formulating initiatives to improve the Teacher Education Program of St. Paul University Philippines.

\section{Materials and Methods}

\subsection{Research Participants}

The participants of the present study were a cohort of practice teachers of the Academic year 2017-2018 and 2018-2019 in St. Paul University Philippines. The 105 pre-service teachers were assessed by their supervising teachers. There were thirty-eight (38) classroom teachers who were raters of the pre-service teachers' teaching demonstration performance. These teachers were in charge of the overall supervision of the pre-service teachers while they were conducting their classroom demonstrations in their laboratory school in the Basic Education, which were composed of grade school and junior high school students.

Table 1. Background Variables of the Pre-service Teachers

\begin{tabular}{|c|c|c|}
\hline $\begin{array}{c}\text { Background Variables of the } \\
\text { student- teachers }\end{array}$ & $\mathrm{N}(\mathrm{N}=105)$ & $\%$ \\
\hline Gender & & \\
\hline Male & 28 & 26.67 \\
\hline Female & 77 & 73.33 \\
\hline Program of Study & & \\
\hline BEED & 32 & 30.48 \\
\hline BSED & 73 & 69.52 \\
\hline Year Graduated & & \\
\hline AY 2017-2018 & 73 & 69.52 \\
\hline AY 2018-2019 & 32 & 30.48 \\
\hline
\end{tabular}

Table 1 reveals that the pre-service teachers are dominated by the female group, with a total of seventy-seven (77) or $73.33 \%$. The male group is composed of twenty-eight (28) or $26.67 \%$. As regards the program of study, the data show that there are more BSED with a total of seventy-three (73) or $69.52 \%$ as compared to the BEED with a total of thirty-two (32) or $30.48 \%$. According to the year of their graduation, the table shows that there are more pre-service teachers with a total of seventy-three (73) or $69.52 \%$ for academic year $2017-2018$ while thirty-two (32) or $30.48 \%$ for the academic year 2018-2019.

\subsection{Research Model}

The current study utilized the exploratory research model. It is anchored on the theory of David A. Kolb's experiential learning, as he put interest in exploring the processes associated with making sense of concrete experiences. According to Kolb (15), this is a powerful and proven approach to teaching and learning that is based on one incontrovertible reality that is people learn best through experience. He further believed that learning is the process whereby knowledge is created through the transformation of novel experiences, through reflecting, conceptualizing, and then testing its authenticity by applying them to similar future experiences. The present researcher believes in the central place of experience in the learning process. It goes beyond the theories taught in the classroom because it offers a firsthand experience, which further helps in the retention of new concepts. As the pre-service teachers engage themselves in classroom teaching, they are more likely to take ownership of the situation. Their experiences will help them adjust to the transition from being a teacher-student to becoming a professional teacher.

\subsection{Research Design}

This part describes the design methodology, which was utilized in gathering the information and data to come up with this present study, which also explains their appropriateness to the exploration of the different research questions. A mixed-method research design using quantitative and qualitative research was used to gather the pertinent data in this present study. According to Aramo-Immonen (16), mixed methods research is an approach to inquiry that combines both qualitative and quantitative forms. Mixed-methods designs provide researchers across research disciplines, with a rigorous approach to appropriately answer research questions.

In gathering the data as regards the teaching performance of the pre-service teachers, a quantitative research method using a survey questionnaire was adopted. The raters were the teachers who directly supervised the pre-service teachers. Moreover, a qualitative research method was used to gather the data as regards the personal experiences of the pre-service teachers in their laboratory schools. Open-ended questions were asked from the pre-service teachers, and they were answered through an individual narrative essay. The two types of data collection provided validation for each other, which had created a solid foundation on inference and drawing out conclusions of the present study.

\subsection{Research Instrument}

To evaluate the teaching performance of the pre-service teachers, the researcher utilized a tool based on an integrated theoretical framework that defines the different dimensions of effective teaching. The tool is based on the different domains of effective teaching, as defined in the 
National Competency-Based Teacher Standards [NCBTS] (17) framework in the Philippines. The validated questionnaire is composed of the seven (7) qualities a teacher should demonstrate in teaching, namely, Classroom Performance, Personality, Lesson Plan Preparation, Demonstration of Lessons, Methods of Teaching, Classroom Management, and Questioning Skills. Each of these qualities is items that specifically describe them. The second part is a documentary analysis of the teaching experiences of the pre-service teachers, which were drawn out from their submitted narrative essays. The essays were composed during and were finalized after their practice teaching.

\subsection{Data Analysis Techniques}

The data were drawn out from the results of the evaluations of the supervising teachers with their mentees. The data gathered were analyzed using descriptive statistics and interpreted using the following statistical treatments: Frequency and percentage distribution were used to confirm statistical assumptions for the background variables of the participants. The weighted mean was used to interpret the obtained responses with the use of the Likert scale. In determining the participants' teaching performance, the following range and qualitative interpretation were used: 4.20 - 5.00 excellent; 3.40 - 4.19 very good; $2.60-3.39$ good; $1.80-2.59$ fair; and 1.00 1.79 poor. T-test and ANOVA were used to determine the significant difference between teaching performance and the identified variables.

In determining the triumphs, known as the positive experiences and trials, known as the challenging experiences of the pre-service teachers, the narrative essays of the pre-service teachers were gathered and organized. The researcher read several times the pre-service teachers' narrative essays. The identification of words and phrases that were recurrent and predominant for each participant were carried out. The keywords were listed as codes. Keywords and phrases were highlighted to determine the data needed. Recurring themes, opinions, and beliefs were identified. Finally, the researcher organized and analyzed the generated data and clustered them into themes.

\section{Results}

\subsection{Descriptive Statistics of the Pre-service Teachers' Classroom Performance}

This part shows the descriptive statistics of the pre-service teachers' classroom performance. The results further disclose the supervising teachers' assessment of the pre-service teachers' classroom performance. It is noted that in terms of the pre-service teachers' personality, demonstration of lessons, methods of teaching, and classroom management were all assessed by the supervising teachers as Excellent with mean scores of 4.63, $4.26,4.33$ and 4.64 respectively. The results imply that pre-service teachers' personality is strong enough to command respect and attention. The pre-service teachers' demonstrations also indicate that they have an in-depth knowledge of their subject matter, thus, making their lessons more meaningful to the learners. Along with the delivery of lessons is an organized classroom management, which is a critical part of effective classroom instruction. The excellent methods of teaching employed by the pre-service teachers also imply that, in general, they were creative enough to adapt to the techniques of the student's capabilities.

The results further disclose that along with lesson plan preparation and questioning skills, the pre-service teachers were assessed as very good with mean scores of 3.67 and 3.98 , respectively. The results imply that the pre-service teachers still encounter certain weaknesses in developing effective Lesson Plans and their ability to ask critical questions as reflected in table 2. This result may lead to reduced learning among learners. A research conducted revealed that the best-planned lesson is worthless if interesting delivery procedures, along with good classroom management techniques, are not in evidence, as cited by Ahmad [18].

Table 2. Descriptive statistics on the supervising teachers' assessment of the pre-service teachers' classroom performance

\begin{tabular}{|c|c|c|}
\hline $\begin{array}{c}\text { Pre-service Teachers Classroom } \\
\text { Performance }\end{array}$ & $\begin{array}{c}\text { Highest } \\
\text { Mean }\end{array}$ & Description \\
\hline Personality & 4.63 & Excellent \\
\hline Lesson Plan Preparation & 3.67 & Very Good \\
\hline Demonstration of Lessons & 4.26 & Excellent \\
\hline Methods of Teaching & 4.33 & Excellent \\
\hline Classroom Management & 4.64 & Excellent \\
\hline Questioning Skills & 3.98 & Very Good \\
\hline
\end{tabular}

Table 3 determines if there is a significant difference in the teaching performance of the pre-service teachers when grouped according to profile variables as assessed by their supervising teachers. The computed T-test values and probability values are greater than the .005 level of significance, which shows that there is no significant difference in the teaching performance of the pre-service teachers when grouped according to profile variables. The results imply that gender, the program of study, and the year the practice teachers have conducted their practice teaching do not affect their performance significantly as assessed by the supervising teachers. This finding supports a previous study conducted by Batugal [19], which revealed that there is no significant difference in the teaching performance of the pre-service teachers when grouped according to gender and program of study. 
Table 3. T-test result on the significant difference in the performance of the pre-service -teachers when grouped according to profile variables

\begin{tabular}{|c|c|c|c|}
\hline \multirow{2}{*}{ Group Statistics } & Gender & $\begin{array}{c}\text { Program } \\
\text { of Study }\end{array}$ & $\begin{array}{c}\text { Year } \\
\text { Graduated }\end{array}$ \\
\cline { 2 - 4 } & $\mathrm{p}$-value & p-value & p-value \\
\hline $\begin{array}{c}\text { Student Teacher's } \\
\text { Personality }\end{array}$ & .521 & .994 & .721 \\
\hline Lesson Planning & .163 & .071 & .488 \\
\hline Content & .448 & .320 & .794 \\
\hline Teaching Methods & .869 & .331 & .830 \\
\hline $\begin{array}{c}\text { Classroom } \\
\text { Management }\end{array}$ & .842 & .393 & .876 \\
\hline Questioning Skills & .334 & .439 & .493 \\
\hline
\end{tabular}

*significant at .005 level

\subsection{Narrative Essays on the Triumphs and Trials Encountered by the Pre-service Teachers}

This part of the research shows the qualitative results of the pre-service teachers based on their narrative essays in their practice teaching in their laboratory school both in grade school and junior high school.

\subsubsection{Triumphs}

As the researcher explored the narrative essays of the pre-service teachers, two themes emerged from the research data. The major themes identified from the results of this study include self-efficacy/sense of fulfillment and character building.

\section{Theme 1: Self-efficacy}

Notably, the majority of the pre-service teachers have expressed their fulfillment in their practice teaching. These were seen from the write-up of some of the pre-service teachers, as shown below:

It was fearful for the first time facing my students and my supervisor looking at me as I demonstrate my lesson. After some time, I gained my confidence as I continue to teach.

Doing it for the first time with real students made me nervous. I was so shy. As I repeated my demonstrations, little by little, I felt better.

When my supervisor was looking at me, I ran out of words. I did not know what to say. I forgot all those that I have prepared. But my supervisor assured me that I can make it. With that, I was able to do it!

I knew it because I prepared my lesson; that is why it was easier for me to conduct my demonstration lessons.

Facing real students for the first time made me anxious! But I had to do it. I need to conquer my fears. I did it.

At first, I had mixed feelings, excited but fearful... but I made it till the final demonstration.

It was revealed in the responses of the pre-service teachers that through their experiences in the practice teaching, it increased their level of confidence, which ushers them to better prepare for their future teaching career. This result is likewise confirmed in a study conducted by Main \& Hammond [6] that self-efficacy beliefs among the pre-service teachers were generally high and were even higher after their practicum. A similar finding was also noted in the study conducted by Dickson, McMinn \& Kadbey, which shows that teachers with more experience were far more likely to express confidence in their abilities (self-efficacies) [8]. Likewise, in a study conducted by Martins et al. [7], it was revealed that the role of the practicum in the teacher education program and the importance of training supervisors in the implementation and management of the training experience contributed to the student-teachers' self-efficacy development.

\section{Theme 2: Character Building}

As affirmed by some of the pre-service teachers, their experiences as they conducted classroom demonstrations were an opportunity for acquiring values and instilling values to the learners. Their essays indicate the following:

The value of honesty, which I wanted to instill in my students, allowed me to reflect and asked myself, "Do I live out this value so that I am more credible to teach them?"

There were times that my students were not attentive to me, and I was annoyed, but I had to control myself so that I will not give up on them.

It was an opportunity to pray more to ask the guidance of the Holy Spirit. I asked the Lord to use me as His instrument to educate young minds.

I was able to strengthen my patience in dealing with my students.

It was an experience of humility in accepting my weaknesses and courage to go on.

The role of educators cannot be undermined, especially in providing opportunities for learners to grow morally and develop a character. Thus, the school is an avenue where not only a challenging academic environment is created but also an ethical learning community that adheres to the same values taught by teachers anchored on the university's vision and mission.

\subsubsection{Trials}

The study conducted by Caires, Almeida \& Vieira [12], showed the difficulties of student-teachers in their practice-teaching. They indicated the challenges experienced by the pre-service teachers such as stress, sense of weariness, 'vulnerability' and others. The present researcher also outlines the difficulties encountered by the pre-service teachers in their practice teaching. Two themes emerged from the narrative essays, and these are classroom management and production of teaching resources. 


\section{Theme 1: Classroom Management}

The pre-service teachers articulated that they were challenged in terms of handling the learners. It was raised in their narrative essays that a great effort was exerted to sustain the attention of the students. The following were their statements:

\section{It was difficult to catch their [learners] attention! \\ They [learners] are not attentive, and I wanted to give up... \\ 'Twas head breaking to face my class in the beginning... very few are participating. \\ I got intimidated by the good students. I didn't know what to say.}

Similarly, these results are identified in several pieces of research. Motivating the learners is one of the leading problems in education, an ongoing issue for teachers as cited by Mart 2011 [20]; Edelson, \& Joseph [21]; Anderman, \& Leake [22].

\section{Theme 2: Production of Teaching Resources}

The production of teaching resources in the delivery of lessons plays a significant role in creating sustained classroom instruction. Its role in the classroom cannot be overemphasized because it brings about the teaching and learning process more effectively. Moreover, the lack of teaching resources may have a negative impact on the teaching-learning process, which has been one of the reasons for the inability to sustain the attention of the learners. The pre-service teachers likewise express their difficulty in preparing educational resources for their classroom demonstrations. They relate that preparing such is time-consuming and costly on their part, especially for large classes.

It was tiring to prepare visual aids...

Expensive...I had to spend my allowance to buy my materials.

Needs time to prepare...

I spent nights to prepare my materials.

I wanted to make better visual aids but I didn't have all the materials I need.

A similar result was also found in a research conducted by Ganal, Andaya, \& Guiab [23], where student-teachers generally spend for their instructional materials so that preparing would be costly on their part. They further narrate that they spent until the wee hours in the morning preparing their materials for teaching. This claim is likewise supported in a research conducted by Cakir [24], and the descriptive results revealed that most of the teachers were reluctant to use many of the highly beneficial materials due to reasons including overcrowded classes, limited technological knowledge, lack of time for preparation, curricular time constraints, heavy workload, burnout and the like.

\section{Conclusions and Implications}

Teaching is a vocation that calls every teacher and aspirants to a unique mission. This mission involves self-sacrifice, which is anchored on the inner drive in shaping and forming the young minds of the learners. Teachers touch lives, and they create windows for the learners to see myriads of opportunities.

This research explored the extent of the pre-service teachers' performance and likewise dealt on the narrative experiences in the conduct of their practice teaching. The results of this present study serve to assist teacher education administrators in designing a more effective practicum program and building effective pre-service teachers' development. Besides, the mentors and supervisors will benefit from this study in providing authentic hands-on experiences in teaching so that the pre-service teachers can demonstrate with proficiency the required teaching competencies. These are the set of skills and abilities, both technical and behavioral, required for the desired level of performance, namely: Personality, Lesson Planning, Content, Teaching Methods, Classroom Management, and Questioning Skills. The researcher believes that a well-planned practice teaching has the potential to launch emerging educators to the path of success. Providing pre-service teachers with a worldview perspective will influence them to greater chances of achievement. The laboratory school where the pre-service teachers were deployed was a potent avenue to strengthen their wills to embrace their mission to form and educate the young fully. Gujjar, Naoreen, Saifi \& Bajwa [25] claim that the theories and concepts in teaching are applied by the pre-service teachers themselves, thus, allowing them to increase their knowledge, do experiments based on acquired knowledge and solve the problems related to teaching. The paradoxical comment of one student-teacher as she expressed in her narrative essay that teaching is "challenging yet fulfilling," conveys a positive message which manifests the Filipinos' sense of resilience. Finally, both positive and challenging practice teaching experiences of the pre-service teachers ushered them to the recognition of significant values related to teaching and further developed a deeper understanding of educational principles and their implications for learning. Future work may focus on constructing similar researches on a larger scale in a new context, location, and culture to gain further insights and more reliable results regarding issues concerning pre-service teachers' performance, limitations, and challenges in their practicum. The results will be a basis for planning and implementation.

\section{REFERENCES}

[1] Buijs JA. Teaching: profession or vocation?. Journal of 
Catholic Education. 2005;8(3):326-45. doi $10.15365 /$ joce. 0803042013

[2] Jusoh Z. Teaching practicum: Student teachers' perspectives. Research, renovation and reinforcement: Enhancing quality in language education. 2013:886-74.

url:http://litu.tu.ac.th/FLLT2013/www.fllt2013.org/private_ folder/Proceeding/865.pdf

[3] Ulla MB. Pre-service teacher training programs in the Philippines: The student-teachers practicum teaching experience. EFL journal. 2016 Nov 30;1(3):235-50. doi: http://dx.doi.org/10.21462/eflj.v1i3.23

[4] Anderson D, Lawson B, Mayer-Smith J. Investigating the impact of a practicum experience in an aquarium on pre-service teachers. Teaching Education. 2006 Dec 1;17(4):341-53.

https://doi.org/10.1080/10476210601017527

[5] Grootenboer P. The impact of the school-based practicum on pre-service teachers' affective development in mathematics. Mathematics Teacher Education and Development. 2006;7(1):18-32.

url:https://researchoutput.csu.edu.au/ws/portalfiles/portal/8 683958/165093.pdf

[6] Main S, Hammond L. Best Practice or Most Practiced? Pre-Service Teachers' Beliefs about Effective Behaviour Management Strategies and Reported Self-Efficacy. Australian Journal of Teacher Education. 2008 Aug;33(4):n4.

http://dx.doi.org/10.14221/ajte.2008v33n4.3

[7] Martins M, Costa J, Onofre M. Practicum experiences as sources of pre-service teachers' self-efficacy. European Journal of Teacher Education. 2015 Apr 3;38(2):263-79. https://doi.org/10.1080/02619768.2014.968705

[8] Dickson M, McMinn M, Kadbey H. Do years of teaching experience make a difference for teachers working in $\mathrm{Abu}$ Dhabi government schools?. CJES [Internet]. 31Dec.2019 [cited 8May2020];14(4):471-8. Available from: https://un-pub.eu/ojs/index.php/cjes/article/view/347

[9] Bandura A. Social foundations of thought and action. Englewood Cliffs, NJ. 1986;1986.

[10] Knowles JG, Skrobola NL, Coolican MJ. We watched them "fail": university supervisors' perceptions of "failure" in student teaching1. International Journal of Qualitative Studies in Education. 1995 Apr 1;8(2):149-70. https://doi.org/10.1080/0951839950080204

[11] Putman SM. Grappling with classroom management: The orientations of pre-service teachers and impact of student teaching. The Teacher Educator. 2009 Sep 23;44(4):232-47 https://doi.org/10.1080/08878730903180226

[12] Caires S, Almeida L, Vieira D. Becoming a teacher: Student teachers' experiences and perceptions about teaching practice. European Journal of Teacher Education. 2012 May 1;35(2):163-78.

https://doi.org/10.1080/02619768.2011.643395
[13] Brown AL, Lee J, Collins D. Does student teaching matter? Investigating pre-service teachers' sense of efficacy and preparedness. Teaching Education. 2015 Jan 2;26(1):77-93. https://doi.org/10.1080/10476210.2014.957666

[14] Plotnikova N, Strukov EN. Integration of teamwork and critical thinking skills in the process of teaching students. CJES [Internet]. 28Mar.2019 [cited 9May2020];14(1):1-0. Available from:https:/un-pub.eu/ojs/index.php/cjes/article/ view/4031

[15] Kolb DA. Experiential learning: Experience as the source of learning and development. FT press; 2014 Dec 17.

[16] Aramo-Immonen H. Mixed methods research design. InWorld Summit on Knowledge Society 2011 Sep 21 (pp. 32-43). Springer, Berlin, Heidelberg. URL: https://link.springer.com/chapter/10.1007/978-3-642-35879 -1_5\#citeas

[17] Bilbao, Purita P. ET. al. (, 2008) Curriculum Development. Quezon City, Manila, Philippines: LORIMAR Publishing Inc.

[18] Ahmad M. Application of classroom management strategies in public and private sector at school level in Pakistan. International Journal of Library and Information Science. 2010 Dec; 2(9):177-83. url:http://www.academicjournals.or g/app/webroot/article/article1379427415_Ahmad.pdf

[19] Batugal ML. Original Paper Challenges and Preparedness of Pre-Service Teachers in a Globally Competitive Work Force. World. 2019;6(1). URL:

http://dx.doi.org/10.22158/wjer.v6n1p106

[20] Mart CT. How to Sustain Students' Motivation in a Learning Environment. Online submission. 2011 May 3. Mart, C. T. (2011). url: https://files.eric.ed.gov/fulltext/ED519165.pdf

[21] Edelson DC, Joseph DM. Motivating active learning: A design framework for interest driven learning. DBRC Publications. Retrieved on March. 2001;1:2005

[22] Anderman LH, Leake VS. The ABCs of motivation: An alternative framework for teaching pre-service teachers about motivation. The Clearing House. 2005 May 1;78(5):192-6. url: https://www.jstor.org/stable/30189907

[23] Ganal NN, Andaya OJ, Guiab MR. Problems and difficulties encountered by student teachers of Philippine Normal University Isabela Campus. International Journal of Science and Engineering. 2015;1(9):63-74. url:https://pdfs.semantic scholar.org/3442/13bfb4f66e18f673781fb751f482283c9df6 .pdf

[24] Çakir I. Instructional Materials Commonly Employed by Foreign Language Teachers at Elementary Schools. International Electronic Journal of Elementary Education. 2015;8(1):69-82. url: https://files.eric.ed.gov/fulltext/EJ107 8841.pdf

[25] Gujjar AA, Naoreen B, Saifi S, Bajwa MJ. Teaching Practice: Problems and Issues in Pakistan. International Online Journal of Educational Sciences. 2010 Aug 1;2(2). url:http://mts.iojes.net/userfiles/Article/IOJES_319.pdf 